\title{
Remodelling reparation: changes in the compensation of victims of natural catastrophes in Belgium and the Netherlands
}

Citation for published version (APA):

Bruggeman, V., Faure, M. G., \& Haritz, M. M. (2011). Remodelling reparation: changes in the compensation of victims of natural catastrophes in Belgium and the Netherlands. Disasters, 35(4), 766788. https://doi.org/10.1111/j.1467-7717.2011.01233.x

Document status and date:

Published: 01/10/2011

DOI:

10.1111/j.1467-7717.2011.01233.x

Document Version:

Publisher's PDF, also known as Version of record

Document license:

Taverne

Please check the document version of this publication:

- A submitted manuscript is the version of the article upon submission and before peer-review. There can be important differences between the submitted version and the official published version of record.

People interested in the research are advised to contact the author for the final version of the publication, or visit the DOI to the publisher's website.

- The final author version and the galley proof are versions of the publication after peer review.

- The final published version features the final layout of the paper including the volume, issue and page numbers.

Link to publication

\footnotetext{
General rights rights.

- You may freely distribute the URL identifying the publication in the public portal. please follow below link for the End User Agreement:

www.umlib.nl/taverne-license

Take down policy

If you believe that this document breaches copyright please contact us at:

repository@maastrichtuniversity.nl

providing details and we will investigate your claim.
}

Copyright and moral rights for the publications made accessible in the public portal are retained by the authors and/or other copyright owners and it is a condition of accessing publications that users recognise and abide by the legal requirements associated with these

- Users may download and print one copy of any publication from the public portal for the purpose of private study or research.

- You may not further distribute the material or use it for any profit-making activity or commercial gain

If the publication is distributed under the terms of Article $25 \mathrm{fa}$ of the Dutch Copyright Act, indicated by the "Taverne" license above, 


\title{
Remodelling reparation: changes in the compensation of victims of natural catastrophes in Belgium and the Netherlands
}

\author{
Véronique Bruggeman, Michael Faure and Miriam Haritz'
}

The paper presents a comparative analysis of the development and present state of compensation for victims of catastrophes in Belgium and the Netherlands. These two neighbouring countries have both seen legislative changes in this field in recent years, albeit with different outcomes. The paper thus analyses to what extent the two compensation scheme structures allow for conclusions as to the comparative benefits of a comprehensive insurance scheme for natural disasters. From the perspective of law and economics, the evolution of private insurance and public intervention through compensation funds, the preference for private or public solutions and the actual financing of these are examined. Drawing on practical experience, such as the case of flood risks, the solutions are tested in view of incentive-based financing. The paper concludes that the private insurance market is more developed in Belgium than it is in the Netherlands, where the reform process has not yet ended.

Keywords: Belgium, compensation funds, first-party insurance, flooding, incentivebased financing, natural catastrophes, the Netherlands

\section{Introduction}

The way in which victims of natural catastrophes can be compensated has been subject to a lot of debate in both Belgium and the Netherlands and interesting legislative changes have occurred recently that make it worth addressing these two specific cases. The types of natural catastrophes to which these two neighbouring countries are exposed are relatively limited. The most extensive damage can be caused by storms, heavy rainfall and flooding (this is especially true in the Netherlands where a large part of the country is situated below sea level, but is also the case for Belgium, which has many surface waters), although there is the possibility of an exceptional earthquakethere have been instances in the province of Limburg in the Netherlands. Moreover, the various studies on the potential consequences of climate change, as listed in IPCC (2007), make clear that Belgium and the Netherlands are potentially exposed to increasingly severe natural catastrophes.

In particular, a few large flooding incidents in the I990s, affecting the Netherlands in particular but also to some extent Belgium, raised questions about the viability of the then existing compensation models. This was especially painful since a large flood that occurred in I993 (due to high water levels in the Rhine-Meuse delta) 
happened again two years later, resulting in the flooding of low-lying areas in the extreme south of the Netherlands.

It is important to mention that in debates on reform of the compensation system in both countries the system in existence in France since 1982 has played an important role. ${ }^{2}$ There, all individuals who have taken out a first-party property damage insurance policy have to pay a supplementary premium for mandatory coverage of natural disasters. The French system has been received enthusiastically by law and economics scholars (see, for example, Schwarze and Wagner, 2004; Lafay, Cannarsa and Moréteau, 2006). After Hurricane Katrina of August 2005, some have even argued that comprehensive natural disaster insurance, similar to the French model, is a solution that should be applied on a much wider scale (see, for example, Kunreuther, 2006a).

The reason these authors chose to look at Belgium and the Netherlands is that, despite their geographical proximity, their legal systems follow remarkably different approaches to compensation of victims of natural catastrophes. Belgium opted in 2005 to move to a model of comprehensive mandatory insurance, whereas the Netherlands still has a policy that mainly consists of ad hoc compensation by government in the event of large-scale damage. However, the introduction of compulsory insurance in Belgium was difficult since it was feared that persons not exposed to the risk of natural disaster also would have to contribute to the compulsory insurance scheme, thus incurring the risk of a negative redistribution. In the Netherlands, meanwhile, the absence of a comprehensive insurance solution is severely criticised because ad hoc compensation not only leads to high pressure on public budgets but also to inequality: victims of some disasters may be compensated whereas others may receive nothing.

A critical comparison of the two systems allows one to test the suggestions in behavioural (Slovic, Kunreuther and White, 200o) and in law and economics (Kunreuther, I968) literature. This literature generally holds that it is possible to structure a comprehensive mandatory insurance scheme that provides affordable and efficient compensation to victims of natural catastrophes. The main research question here, therefore, is whether the actual structure of the compensation schemes in Belgium and the Netherlands offers insights on the comparative benefits of such schemes for natural disasters. An obvious additional and equally interesting question is why a nation like Belgium has opted for a comprehensive insurance scheme while a neighbouring state (the Netherlands) has not. This paper provides a few indications of those reasons, but it would be beyond its scope to include a detailed analysis of the (mainly political) reasons why the solutions of the two countries differ.

This paper first sketches out the compensation system in Belgium (section 2) and then the system in the Netherlands (section 3), discussing only compensation regimes specifically designed for victims of natural catastrophes (insurance, compensation funds, and other forms of government intervention). ${ }^{3}$ In this respect, not only is the current system outlined, but also the historical evolution as well as the reasons for recent legislative changes. Of course, not all of the legal details of the system are described; only those that are crucial from the perspective of this contribution (law 
and economics methodology — see Posner, 2007). Thus the study focuses mainly on the financing of the system (whether it is private or public), the compensation provided, the involvement of government, and the matter of whether the system offers incentives for prevention (via risk differentiation in the financing of the compensation or otherwise). The paper goes on to compare the two systems (section 4), using insights from economic analysis of law, and to make a few concluding remarks (section 5). One should note, however, that the general question of whether and to what extent private insurance results in better compensation than public catastrophe funds does not form part of this analysis (for more on this topic see Endres, Ohl and Rundshagen, 2003; Gollier, 2005). The aim of the paper is thus to present a comparative analysis from a law and economics standpoint that is insightful with regard to policy choices and decision-making vis-à-vis the compensation of victims of natural catastrophes.

\section{Belgium}

\section{Introduction}

While Belgium is exposed to a number of natural hazards, there have been few significant catastrophic losses in the past few years. Nevertheless, as regards the flooding risk in Flanders, the Administration for Environment, Nature, Land and Water Management (AMINAL) of the Ministry of the Flemish Region calculated that 72,000 hectares, or five per cent of the territory of the Flemish Region, could be demarcated as flood-prone, of which 6,I66 hectares is situated in residential zones. Therefore, based on an average surface of 784 square metres per property, between 60,000 and 80,000 residences are represented. ${ }^{4}$

Until 2003, Belgium only had a patchwork of regulations directly or indirectly applicable to victims of natural catastrophes searching for full compensation. Indeed, tort law, insurance law, various branches of social security law, and general solidarity needed to be cumulated to achieve financial compensation (Bernauw, 2006). Theoretically, victims could call on liability law to seek (full) compensation. However, tort law can apply only when a liable tortfeasor can be found, which rarely will be the case after a natural catastrophe. Hence, the victim will have to rely on other sources of compensation. Yet, the majority of the existing legislation from the other branches of law granted only partial compensation, and several conditions had to be met and procedures usually took a long time. This situation changed drastically in 2005, when new legislation on compensation of victims of natural catastrophes was approved.

\section{Evolution of insurance coverage}

After a whirlwind caused considerable damage in January 1976 to some parts of Belgium, the Council of Ministers took the decision to elaborate basic legislation allowing for reparation of damage to private property due to natural disasters. The 
'Act of I2 July I976 on the Repair of Certain Damage Caused to Private Goods by Natural Disasters', which also is applicable to agricultural damage caused by natural disasters, installed a so-called Disaster Fund (part of the National Cash Registry for Disaster Damage). This Disaster Fund is financed in the aftermath of a natural catastrophe by advances from the Treasury, loans and, where necessary, allocations drawn from the state budget, gifts, legacies and profits from the National Lottery. The Disaster Fund compensates, in instalments, for direct material damage caused by such a natural disaster, up to the amount of EUR 64,800, while a deductible of EUR 250 is applied-on the condition that the total direct damage to private goods amounts to at least EUR I,250,000 and the average damage amounts to at least EUR 5,000 per family. There will be full compensation only if the granted money is used for restoration or construction works within the following three years.

The Disaster Fund cannot be considered a great success since citizens have to wait a considerable amount of time before receiving compensation for damage, the government has to recognise the event as a natural disaster, ${ }^{5}$ and filing an application is a very complex procedure (Durant, 2006, pp. 72-73). Moreover, compensation is granted only up to a certain amount, determined in accordance with statutory criteria, without taking into consideration real damage (Bernauw, 2006, pp. I55-I57). Furthermore, the area of application of the Act of 1976 is specified narrowly and the damage arising from risks that under normal circumstances would be covered by insurance policies, such as fire, lightning, explosions, hail or a storm, is excluded a priori from compensation. Finally, the legislature opted for a system whereby the financing mechanism only becomes operative from the moment a catastrophe occurs.

Since the Disaster Fund is financed by general taxpayers in accordance with the notion of solidarity, the Government of Belgium searched for other ways to provide financial compensation for natural catastrophes, such as by calling on the insurance industry. The promulgation of the 'Royal Decree of 24 December 1992 on the Insurance against Fire and Other Dangers as concerns the Simple Risks' was a first, albeit small, step forward. This Royal Decree is applicable to those insurance agreements in which simple risks ${ }^{6}$ are in the main insured ${ }^{7}$ against damage due to: I) fire and related dangers (such as a lightning strike, explosion, implosion, and contact with an aircraft or any other vehicle or animal); 2) electricity; 3) attacks and labour conflicts; 4) storm, hail, ice and snow pressure; 5) natural disasters; 6) water; 7) broken windows; 8) theft; 9) indirect losses; and Io) industrial damage for which daily compensation is guaranteed.

The first category of risk (fire and related dangers) normally falls under the general fire insurance coverage, unless otherwise agreed (Art. 6I, I992 Insurance Act). Therefore, if the insurance agreement does not include a stipulation, the risks will be statutorily included in the fire insurance agreement. In this sense, they make up 'optional coverage'. The other risk categories, except 3), are also facultative cover, but will be included in the fire insurance agreement only if stipulated explicitly (Colle, 2005, pp. 8-20). Damage due to a storm, hail, ice, snow pressure and natural disasters in general thus could be included voluntarily in the insurance agreement covering 
simple risks. The third category (attacks and labour conflicts), though, is included mandatorily in the fire insurance agreement. As will be shown below, mandatory coverage was extended later to include storms (through the Royal Decree of I6 January I995, amending the Royal Decree of 24 December I992) and natural disasters (through the Act of I7 September 2005, amending the I992 Insurance Act).

Although damage caused by storms in principle could be (partially) covered by most fire insurance policies, the Disaster Fund did pay out EUR I5,284,632 of compensation after windstorm Daria hit the country in I990. Consequently, the Fund was not able to build up a financial reserve, and the former Minister of Economic Affairs, Willy Claes, proposed in 1990 and in 1992 to transfer the task of the Disaster Fund to the private insurance sector (Nijs, 200I). This is one of the reasons why the Royal Decree of I6 January I995 established that 'storm coverage'-which legally comprises hail, ice and snow pressure - would be an obligatory extension of every fire insurance policy that concerns simple risks. ${ }^{8}$ The legal rule is now based on the principle that property will be mandatorily insured against storms that have a wind speed of no less than Ioo kilometres per hour. Furthermore, the Royal Decree foresees a minimum level of coverage and authorises the exclusion of those goods that are highly vulnerable to the storm risk (such as light or easily movable constructions, open buildings and bell towers).

The Act of 2I May 2003, modifying the 'Act of 25 June 1992 on the Land Insurance Agreement', and the 'Act of I2 July 1976 on the Repair of Certain Damage Caused to Private Goods by Natural Disasters', in turn introduced flood coverage as a mandatory extension to the fire insurance policies concerning simple risks (in the same way as storm coverage had been introduced in 1995) (Termote, I998, 2000, 2003; Van Schoubroeck, 2003; Leyssen, 2005; Celis and de Graeve, 2006).9 This mandatory extension only applies however to property situated in flood-prone areas (an optional extension is available for property outside this risk area), which had to be demarcated by the country's three Regions. As a result, the Disaster Fund no longer needs to intervene since flood risk is insured or at least insurable. The Act of I976, though, continues to exist for those events and property not included in the Act of 2003, namely for those goods that are not insured because of the low financial capabilities of the victim, and for agricultural damage. In addition, the Act of 2003 foresees the creation of an Office of Tariffication, providing insurance to those who do not have any coverage because either no agent is willing to assume the risk or the requested premium is too high.

\section{Act of 17 September 2005}

The Act of 2I May 2003 did not enter into force, however, mainly due to difficulties with the demarcation of the flood-prone areas (Colle, 2005-06). In addition, the Ministerial Council decided on 23 January 2004 to consolidate the loan that it had granted to the Disaster Fund. ${ }^{\text {Io }}$ The Belgian state then argued that it would be better off if a new act transferred coverage of natural disasters to the insurance sector. Therefore, the Act of 2003 was amended by the Act of I7 September 2005, building 
on the former legal provisions (Assuralia, 2005; Colle, 2005-06; Bernauw, 2006; de Graeve, 2006; Termote, 2006).

The Belgian legislature created general solidarity between all citizens who buy fire insurance for the so-called simple risks-comprising 90-95 per cent of the Belgian population - by introducing a mandatory extension to natural disaster coverage. The latter consists of four perils: flooding (referring to water that comes from below); earthquakes; the flowing over or the impoundment of public sewers; and a landslide or subsidence. Fire insurance for simple risks and coverage for natural catastrophes are bound up inextricably, meaning that if the fire insurer refuses to offer coverage for natural disasters, he/she cannot offer any longer fire insurance itself. ${ }^{\text {II }}$ The extra insurance premium will be adjusted to every individual case accordingly and one can expect it to be between EUR 3-4 per EUR 25,000 insured. The maximum indexed deductible for disaster coverage amounts to EUR 6Io per claim.

This way, at least all direct damage to the insured property caused by a natural catastrophe or by an insured peril that results directly from it (notably fire, explosion or implosion) as well as damage to the insured property due to measures taken by a legally constituted authority to safeguard and protect goods and persons, the clearance and demolition expenses associated with reconstruction of the property, and accommodation costs in the three months following the catastrophe (if the dwelling became uninhabitable) are compensated. Non-gathered crops, soil, objects located outside of the building (except if they are permanently attached), easily movable constructions, garden houses and vehicles, among other things, are excluded from retribution, unless otherwise stipulated.

Furthermore, each insurer has been given some limits regarding the monetary burden he/she should bear, since disaster coverage concerns catastrophic risks that can reach extraordinary proportions - the ratio legis being to avoid the financial downfall of the insurance companies. Indeed, a limit per insurance company (instead of a global limit for the insurance market) has the advantage that the insurer can calculate precisely the maximum risks he/she is taking and thus find reinsurance more easily (Art. 68-8 $\ 2$, I992 Insurance Act). When this limit is attained, the National Cash Registry for Disaster Damage intervenes with a general upper limit of EUR 280 million (EUR 700 million for earthquakes) per event (Art. 34-I, 34-2, I ${ }^{\circ}$ and 34-3 of the Act of I2 July I976). If these amounts turn out not be sufficient to compensate the victims fully, the intervention of the Cash Registry will be reduced in proportion.

These limits seem adequate to compensate for most losses, especially considering the fact that granted compensations for the three most destructive natural catastrophes that have hit Belgium since 1976 (namely the storms of 25-26 January I990, the earthquake of 8 November I983 at Liège/Luik, and the abundant rains of I3-I5 September 1998) amounted to EUR 74.7 million, EUR 42 million and EUR 38.125 million, respectively. ${ }^{12}$

In addition, the 2005 Act has set up an Office of Tariffication. The insurance sector has calculated that between three and four per cent of the insured risks for 
fire damage are in fact uninsurable for flooding and that more or less eight per cent of those insured against fire coverage will see a doubling of the premium. It is for these risks that the Office of Tariffication will specify the premium conditions.

To conclude, the Act of I 7 September 2005 allows victims of natural catastrophes to direct themselves to their fire insurer (as long as their damage relates to the simple risks in the sense of the fire insurance) without recourse to the Disaster Fund, which is advantageous for both the victim and the Belgian state (Colle, 2005-06, p. 885). As far as the victim is concerned, the long and often complicated administrative procedure associated with the Disaster Fund is avoided. The damaging natural peril no longer needs to be declared a natural catastrophe by the Ministerial Council. As for the Belgian state, the main burden of compensating the victims of natural catastrophes is now borne by the insurers. The Disaster Fund only intervenes if the limit of the individual insurance company has been reached and if the damaged property is not insured due to the financial position of the victim.

\section{The Netherlands}

\section{Introduction}

In the past decennium the Netherlands has suffered various types of catastrophe, both natural (such as an earthquake in southern Limburg (1992) and heavy rain and flooding in the southeast (I993-95)), and, principally, man-made (such as a legionella epidemic in Bovenkarspel (I999), an explosion at a fireworks factory in Enschede (2000) and a large fire at a cafe in Volendam (on New Year's Eve 2000-0I)). In all of these cases the question arose as to what legal instruments could be used to provide compensation. In this respect tort law possibilities were examined, and, more particularly, attempts were made to make the government liable for natural catastrophes (Muller and Stolker, 200Ia, 200Ib; Van den Wall Bake et al. 2004; Van Ravels, 2006), especially when damage cannot be compensated in the 'normal' way (first-party insurance, tort liability or liability insurance). As a consequence, victims often will address the only solvent debtor: the government—as when damage occurs for which victims would have liked to take out insurance, but where coverage was unavailable (Faure and Hartlief, 200Ia, pp. I5I et seq.; Van de Bunt, 200I, pp. I76 et seq.).

Since victims frequently approach the government for compensation (also based on tort law), the Government of the Netherlands has indeed intervened on various occasions using the public budget to provide ad hoc compensation to the victims, although legal arrangements in this regard are not unified and have been the subject of criticism. As is shown below, a specific Act-Wet Tegemoetkoming Schade bij Rampen en Zware Ongevallen (WTS) — was created in 1998 with the aim of providing compensation to the victims of catastrophes and severe accidents. However, in practice, it appears that the WTS often has not been applied to cases where many people suffered harm as a result of a disaster. Therefore, in addition to the statutory 
arrangement in the WTS, the Government of the Netherlands (and other organisations) also has created ad hoc solutions for specific victims. The main problems with respect to the insurability of disasters and the solutions via these collective arrangements are addressed below.

\section{Evolution of insurance coverage}

In the I950s Dutch insurers issued so-called binding decisions, applying to all their members, prohibiting them from insuring flood and earthquake risks (the latter being relatively small in the Netherlands with the exception of the area around southern Limburg) (Hartlief, I995, pp. I42-I43). The argument of the insurers was that these risks were technically not insurable and that therefore all of their members should refrain from covering them (Faure and Hartlief, 2003, pp. 223-225). They claimed that they were concerned that a natural disaster could cause billions of Euros of damage and that they had too little statistical material to calculate premiums, thus fearing adverse selection. It was argued that only those who would be largely exposed to the risk would have a demand for insurance; others would have no need for coverage, leading to a situation of adverse selection. Consequently, those who faced the risk of being affected by a natural disaster could not receive coverage simply because insurers had agreed not to cover those risks. In the literature, though, it has been held that the arguments of insurers concerning adverse selection (which would make the risk uninsurable) are wrong, since the traditional remedy for adverse selection, namely risk differentiation, is considered to be applicable to insurance of natural disasters as well. Some citizens may not require coverage at all, in which case there is no point in making coverage for them compulsory. Others may be exposed, such as to the risk of flooding, but the risk may be minor. Still others, living in riskier areas, may be exposed to a greater threat.

Classic principles of insurance teach that adequate differentiation between the risks - with corresponding differentiated premiums — can provide an adequate remedy for adverse selection and thus make the risks generated by natural disasters to an important extent insurable as well (Priest, 1996). However, one should still differentiate between the various types of natural hazards. Storm damage, for example, is covered since there is no adverse selection and there are sufficient statistical data and good loss models that can predict probable maximum losses. Flood losses, though, can lead to very high potential damage, even exceeding the possibilities of the insurance market. Intervention by the government may be required to cover these high losses (Froot, I999; Kunreuther and Michel-Kerjan, 2004; Gollier, 2005).

As a result of an earthquake close to Roermond in 1992 and the flooding of the River Meuse in 1993 these binding decisions came under increasing political pressure. The binding decision concerning earthquakes was quickly withdrawn, and insurers came under increased pressure to abrogate the binding decision on flooding. In part this was to do with political pressure on insurers, as can be seen, for instance, by the questions that were put to the government during the parliamentary proceedings. ${ }^{13}$ But it was due also to the concerns of the European competition authorities since 
the binding decision clearly violated the conditions of Regulation 3932/92 of 2 I December 1992 on the application of Article 85 (3) of the 'Treaty to certain categories of agreements, decisions and concerted practices in the insurance sector. ${ }^{14}{ }^{14}$ Levie and Cousy (I994) have commented on this exemption regulation, which states that standard policy conditions in particular may not contain any systematic exclusion of specific types of risk without providing for the express possibility of including that cover by agreement (see Consideration 8 preceding the exemption of the Regulation, as well as Article 7 (I) (a) of the exemption, reflecting that non-competitive practices are apparently not an exception in Dutch insurance practice). The binding decision was subsequently withdrawn in I998. ${ }^{\text {Is }}$

Negotiations then took place between the government and the insurers on a new system of coverage for natural disasters, with the French model playing an important part. These debates finally led to the introduction of the WTS I998, providing for public compensation in the event that the damage is uninsurable (as discussed below). In addition, by the end of the I990s, Dutch insurers gave in to political pressure and announced that they were prepared to cover damage caused by heavy rain, as can be seen in a letter of the Secretary of State of Internal Affairs Gijs de Vries. ${ }^{16}$ The fact that the public funding mechanism offered under the WTS I998 was not applicable to cases where risks in principle would be insurable played an important role in this respect. As a result, damage due to heavy rainfall became insurable.

Indeed, the Dutch Association of Insurers advised, in 1999, that insurance against heavy rainfall be included in the existing building, fire and theft, and contents covers (Kok, Dooper and Lammers, 2000). Damage due to rainfall, including the overflow risk of dikes and quays, should be covered for both private individuals and companies. Damage resulting from the flooding of rivers not originating in the Netherlands and saltwater flooding remains uninsurable. The WTS 1998 gives citizens and companies the right of compensation when insurance possibilities are exhausted.

In addition, the Dutch Association of Insurers agreed in 2002 to offer agricultural water damage insurance through a pool, covering damage up to an amount of EUR 50 million, backed by a guarantee of the central government for an amount between EUR 50 and IOO million with a deductible of 25 per cent if the damage is higher. ${ }^{17}$ The insurance is meant to cover in particular crop damage due to heavy rain. The agricultural sector also agreed that in such a case it would not call for compensation from the government on an ad hoc basis. However, the WTS I998 would still remain applicable, for instance in the event of damage caused by flooding. Yet, since the guarantee of the central government principally constitutes state aid, the European State Aid procedure had to be followed, as can be seen from the letter of the Minister of Agriculture, Cornelis Pieter Veerman of II April 2003. ${ }^{18}$ On Is October 2003, the European Commission approved the subsidy provided by the central government in the form of a guarantee. ${ }^{19}$ Thereon, it became possible for the market to start developing these crop damage insurances, which led to the institution of two pools, called Agriver and OWM AquaPol ${ }^{20}$ (formerly LTO Aquapol), which both applied for the subsidy in the form of a guarantee by the central government. Since I9 March 
2004 Agriver has offered insurance for crop damage against the consequences of heavy rain, subsidised by a guarantee of the central government. ${ }^{21}$ In 2007 , crop insurance was expanded to include compensation of damage to crops in the fruitfarming sector caused by extreme frost. The European Commission approved this extension of the regulation on I9 June $2007 .{ }^{22}$ The Dutch state hereby provides a subsidy in the form of a guarantee as a stimulus for insurance companies, ranging from EUR 6,677,400 to a maximum of EUR 20,927,400 per year for frost damage, with a total insured value of EUR 762.6 million. Furthermore, the decision of the European Commission altered the state aid rules regarding the first branch of crop insurance. In both cases, a deductible of 25 per cent per crop applies. It is noteworthy that governmental intervention thereby facilitated the insurability of the risk caused by a catastrophe, especially crop damage caused by heavy rainfall and extreme frost.

This course of events makes clear that although there are undoubtedly great benefits to cooperation between insurers, the case of the Dutch binding decisions indicates that this cooperation may effectively also limit or even exclude coverage. Even when the binding decisions were abrogated, the negotiations between the Government of the Netherlands and the Dutch Association of Insurers determined the conditions for covering damage caused by natural disasters. According to legal doctrine, this shows that an effective competition policy is in great need in order to generate a wide and differentiated supply of insurance policies (Faure and Van den Bergh, 2002).

\section{WTS 1998}

In the I990s debate on compensation for victims of catastrophes, more particularly of flooding, the Government of the Netherlands originally argued against the French solution since it was feared that free consumer choice would be limited and that this compulsory system would lead to increased costs for the citizen. ${ }^{23}$ Subsequently, the government apparently considered these problems as less important, introducing a draft largely similar to the French framework: a fund would be installed financed through a tax on housing insurance. All of those insured (bad or good risks) would have to pay the tax. However, the Dutch Council of State formulated negative advice concerning this draft, stating that it would be preferable to let the government finance this risk and that it would be possible to insure the flooding risk. ${ }^{24}$ Hence, the government decided to withdraw the draft.

In the next phase the Belgium example of the Disaster Fund of 1976 became the model for the WTS, an Act on compensation of damage in the event of catastrophes and large accidents. The goal of the WTS was to offer a more structural solution to compensation of victims of catastrophes instead of a system of ad hoc responses. De Vries (1998) and de Groot (2004) have analysed in detail how the WTS provides a right to compensation for damage and have specified the main principles of compensation: it is applicable in the case of fresh water flooding or earthquakes that are considered a catastrophe or a large accident in the sense set out in the Act. However, Article 3 of the WTS provides that it can be also declared applicable through a Royal Decree, which can come into being only if the government considers the incident 
a catastrophe or a large accident. The parliamentary proceedings make clear that such an accident at least requires that many governmental organisations and services of various disciplines must have intervened in a coordinated way and that the accident has endangered the health of many persons and caused substantial damage. ${ }^{25}$

The WTS clearly has a subsidiary character, as is made clear in the Act itself. Article 4, for instance, provides that the victim will receive compensation for particular types of damage, including damage to a dwelling, commercial loss and property damage. Other forms of damage also can be declared to fall under the scope of the WTS, but pure economic loss will not be compensated since this is considered a normal business risk. ${ }^{26}$ Very important is that Article 4, 3 of the WTS stipulates that the victim is not entitled to compensation when the damage was reasonably insurable or when the victim was able to obtain compensation from another source. The parliamentary proceedings made clear that damage is considered as reasonably insurable when it is not generally excluded from coverage and when it is generally insurable without limiting conditions or excessively high costs, which gives rise to the question: in what respect damage resulting from natural disasters can be considered insurable? It is explicitly noted, therefore, that damage to motor vehicles, for example, will not be compensated through the WTS since this type of damage is insurable and is covered under commercial insurance. ${ }^{27}$ If, however, insurance were theoretically possible, but victims did not take up the possibility because the premium charged would not be proportional to the coverage provided, the WTS may be applicable again. ${ }^{28}$

The subsidiary nature of the WTS also has consequences for the relationship with liability law. Indeed, a consequence of Article 4, 3 is that damage should not be recoverable from another source. The practice has shown that, as a result, the WTS may not be applicable in all cases of man-made disasters when in principle damage can be claimed from a liable injurer. Therefore, the WTS only can be applicable in the case of damage due to natural disasters (Faure and Hartlief, 20oIb, pp. 24I et seq.). Thus, the subsidiarity of the WTS manifests itself in two circumstances: either the WTS is applicable, but certain types of damage are recoverable from another source and hence not covered under the WTS; or the WTS is not applicable at all, given the claim possibilities in tort law.

In fact, the WTS mainly applies to damage caused by heavy rain (Van der Schans, 2000). De Groot (2004, p. I52) claims that in its six years of existence (and even in its I3 years now) the WTS has been applied only four times. The first two times its application concerned cases of heavy rain. Since in both instances the heavy rain did not pertain to a formal flood in the sense of Article I of the WTS, the WTS needed to be declared applicable by Royal Decree. It is remarkable of course that this statutory arrangement, which was specifically created by the legislator to compensate victims of catastrophes, has been applied merely in the case of damage due to heavy rainfall but not in the case of serious man-made disasters resulting in major personal injuries, such as the aforementioned fireworks accident in Enschede in 2000 or the Volendam fire in 2000-OI (Faure and Hartlief, 2006, pp. 218-22I). Thus, the legislator has not succeeded in its (at least implicit) attempt to create with the WTS 
an exclusive arrangement for government contributions in the event of both natural and man-made catastrophes. Hence, it is not surprising that the WTS has been the subject of criticism in the literature.

\section{Criticism}

The Netherlands has suffered several disasters in recent years, some of them natural disasters, but the most striking were man-made events. In many cases there were a large number of victims (28 persons died of legionella infection in Bovenkarspel; I 4 young persons died and some I80 were injured, many seriously, in the fire in Volendam, resulting in an estimated EUR 50 million of personal injury damages; and the explosion at the fireworks factory in Enschede erased an entire neighbourhood and caused the deaths of 23 civilians, the wounding of approximately 950 others, and material damage of an estimated EUR 454 million) and the total amount of damage was high. Consequently, the question arose as to what legal instruments could be used to pay compensation to the victims. Initially, attention was paid to tort law, but given the inherent limits of this system, the focus was extended to other compensation systems as well.

Due to various calls for intervention by the Government of the Netherlands, different ad hoc compensation funds were created, which sometimes had to solve problems of liability law, as in the case of natural disasters, and in other instances offered only a 'gesture' as a sign of solidarity with the victims. The government's attempt to provide a structural compensation arrangement for victims, via the WTS of I998, largely failed since this instrument was not applicable to the major disasters that hit the Netherlands in recent years. The entire system of compensation for victims of catastrophes thus has been seriously criticised in the literature from various perspectives (Hartlief, 2002).

The first criticism relates to the fact that the government intervenes with specific funding for victims of catastrophes on an ad hoc basis. This preference for victims of catastrophes (compared to victims of other accidents) has been criticised from the angle of the equality principle (Bloembergen, I992; Polak, I997). Second, legal doctrine also holds that if specific compensation needs to be provided to victims of catastrophes, then it is more desirable to have a structural solution instead of the current ad hoc arrangements. In this respect, the WTS 1998, which apparently does not serve this goal, would have to be revised. Third it has been stressed that (with an eye on man-made disasters) there might be reasons to increase duties of potential tortfeasors to guarantee their solvency. Fourth, it seems logical to increase the possibilities of first-party insurance, too. Now that the prohibited cartel agreements not to cover the consequences of large-scale flooding and earthquakes have been withdrawn, insurance policies covering those risks could be brought to the market (provided that some kind of solution for large losses is available through reinsurance and/or the government), which is so far only the case for damage due to heavy rainfall (and frost). One should note, however, that, for other relevant natural hazard risks in the Netherlands (storms, lightning and hail), commercial insurance cover is available. 


\section{Reform}

The Government of the Netherlands has installed a body with the specific task of providing an assessment of the WTS I998: the Commissie Tegemoetkoming bij Rampen en Calamiteiten (CTRC) (Commission for Compensation in Cases of Catastrophes and Incidents). It was asked in 200I to provide advice to the government on optimal compensation in the event of catastrophes, ${ }^{29}$ examining first the existing possibilities of compensation and then formulating proposals for desirable additional compensation. Its final report, Solidariteit met Beleid (Solidarity with Policy), was presented to the Minister of the Interior on 7 March 2005 and consists of three parts: a general section and two research reports on the financial settlement of disasters in the Netherlands and the compensation schemes for damage caused by catastrophes in some other countries. The CTRC brought to the fore multiple interesting suggestions regarding financial compensation for victims of catastrophes in the Netherlands, including those listed below.

- Tort law needs to be the primary mechanism for compensating catastrophic damage.

- Judicial liability procedures are to be shortened and simplified by means of the new act on the collective settlement of mass damage..$^{30}$

- Insolvency guarantees for injurers need to be introduced or increased.

- For catastrophes where no liable injurer can be identified the CTRC suggests increased use of first-party insurance. The proposal is designed not to make the purchase of disaster coverage mandatory (as in France), but to facilitate the insurability of risks, on the one hand, by letting the state act as reinsurer (if necessary) and, on the other hand, by pursuing an active information policy.

- Change the WTS into a national solidarity fund that would, on the basis of clear rules and structures, provide various types of compensation, including for uninsurable damage.

Most of these proposals of the Commission are in line with what has been suggested in legal doctrine and as far as the revision of compensation of victims of catastrophes is concerned. On 5 June 2006, the former Minister of the Interior, J.W. Remkes, wrote a letter to parliament outlining the position of the government on the reform proposals of the CTRC. ${ }^{31}$ In that letter, Remkes noted the government's desire to achieve a few fundamental changes on the following basis:

- provision of guarantees or insurance should be made compulsory in cases where a liable injurer can be identified;

- insurance coverage by potential victims has to be stimulated in instances where a liable injurer cannot be identified; and

- the current legislative basis for compensation of victims of catastrophes has to be changed to address the current ad hoc solutions.

A summary of these proposals can be found in Faure and Hartlief (2007, pp. 34I-342). 
The government is therefore strongly suggesting the development of voluntary firstparty insurance, without prescribing a straightforward duty for potential victims to purchase insurance coverage (comparable to the model that exists in France). In the event that insufficient capacity makes the risk hard to insure, the state could act as reinsurer. The general idea behind this new policy is that there would be less pressure on the public budget, but responsibility would be shifted either to the industry for so-called technological disasters or to potential victims for natural catastrophes.

No further action in this respect has been taken at the political level. As of January $20 \mathrm{II}$, it is too early therefore to provide an educated guess as to whether these proposals will be accepted at the political level, although one can say that most likely within the next few years an important revision of the compensation system will take place in the Netherlands.

\section{A critical comparison}

\section{Comparison of the evolution of the systems}

The brief examination of the regulations on compensation of victims of natural catastrophes in Belgium and the Netherlands makes clear that both systems have undergone important evolutions in recent years.

The approaches in the two countries were traditionally quite different. Belgium has had a Disaster Fund since 1976 from which victims of natural catastrophes can receive (limited) compensation. The financing of this fund traditionally occurs through government intervention. Hence, general taxpayers compensate victims of natural catastrophes on the basis of the notion of solidarity. In the Netherlands, meanwhile, from the I950s insurers explicitly excluded natural catastrophes from coverage in the binding decisions of the Dutch Association of Insurers.

At present, the major difference between the two countries is that the system in Belgium seems to have come to an end with the legislative changes of 2005 , whereas the system in the Netherlands is still undergoing revision. Following the suggestions of legal commentators, the former Government of the Netherlands adopted the CTRC proposals aimed at the promotion of the purchase of first-party insurance by victims, but so far nothing further has happened at the legislative level.

In Belgium, the system has clearly moved away from being a mere public mechanism, instituted in the Disaster Fund, towards much stronger involvement of market participants, more particularly, insurance companies. The legal form came with the introduction of mandatory coverage for natural disasters on top of the voluntary fire insurance policy. The main difference between the Belgian Acts of 2003 and 2005 lies in the fact that in 2003 mandatory cover applied only to particular flood-prone areas whereas in 2005 the duty was generalised to all insured having a fire insurance policy for so-called simple risks. As a result of this evolution, the need for the intervention of the Disaster Fund has been substantially reduced. This publically financed fund now intervenes only in cases where the private insurance solutions do not work and in the event of agricultural disasters. 
The evolution of the system in the Netherlands contrasts sharply with that in Belgium mainly because it started with de facto uninsurability created by the insurers themselves, prohibiting the coverage of flooding or earthquake risks. But even after increased political pressure and European Union (EU) competition law considerations led to a withdrawal of these binding decisions, a proper insurance market for damage caused by flood risks never emerged in the Netherlands. Even though insurance solutions were discussed during the establishment of the WTS I998, the latter has created in fact a public fund to cover particular large-scale catastrophes falling under the scope of the Act or declared compensable by the government. Whereas Belgium had started discussions about the abrogation of its Disaster Fund at the end of the twentieth century, the WTS I998 of the Netherlands copied (at the same time, more or less) the example. Today, an insurance solution for flood risks in the Netherlands has been reached only as far as damage due to heavy rainfall is concerned. For other types of flooding there is still no insurance coverage, despite the formulation of several proposals in that regard on behalf of legal doctrine.

Comparing both countries' present solutions from an economic perspective, it is clear that the Belgian framework is more in line with suggestions in economic literature than the current model in the Netherlands. Law and economics scholars have been especially critical of automatic government-provided compensation, such as public fund solutions, warning that these dilute incentives for market participants to take adequate preventive measures for risk reduction (Kaplow, I99i; Epstein, I996). Consequently, some have pleaded strongly in favour of insurance solutions rather than the employment of public funds since the risk differentiation applied by insurance companies could potentially have a positive effect on incentives for prevention (Priest, I996).

The fact that Belgium substantially reduced the role of its Disaster Fund following the legislative changes of 2003 and 2005 and moved towards insurance solutions can be supported therefore. The Netherlands, though, still largely relies on the public fund solution through the WTS I998 and on ad hoc arrangements. The insurance solution in the Netherlands is limited to damage caused by heavy rain. The (implicit) major reliance on public funds in the Netherlands leads to the well-known problem identified in the literature: adequate incentives for prevention by potential victims may not be provided. However, given the low-lying nature of the area, the possibilities of private flood prevention strategies may be limited. Since flood risk prevention largely represents a public good, it has been mainly (understandably) a public and governmental concern.

\section{Private or public solutions?}

An interesting question as far as a comparison between both systems is concerned is to what extent the two countries have used private solutions (insurance) to cover particular catastrophic risks, especially flooding, and to what extent government intervention is still necessary. Arguably, commercial insurance has many benefits, including the explicit premium, which reflects risks and thus can provide incentives. However, commercial insurance rarely provides full cover, and hence some type of government intervention (eventually in the form of the government acting as reinsurer of last resort) may be necessary for very large damage (see Bruggeman, 2010). 
The previous comparative section makes clear the extent to which there is a reliance on either of the two options. The tendency in Belgium is clearly to shift from public to private financing by adding mandatory coverage for flooding to fire insurance, thereby seriously limiting the role of the (public) Disaster Fund. The Netherlands, by contrast, still relies largely on financing through the public budget, despite the CTRC's recommendations for change.

Nevertheless, neither in Belgium nor in the Netherlands can one state that there is total reliance on either private or public solutions. Even though one can say that both countries have increasingly - albeit to different degrees - moved towards an insurance system, government intervention is not totally excluded anywhere. The Disaster Fund still exists in Belgium, even though its function has become more limited. Moreover, the legislature has restricted the risk exposure of insurers and thus provided specific limits up to which the insurer has to intervene; if the level of damage is higher, the Disaster Fund comes into play. Consequently, one can say that a form of public-private partnership has emerged in Belgium.

In the Netherlands, meanwhile, the WTS I998 intervenes in principle only with public funds when damage cannot be recovered from another source, which could be insurance. Given the non-availability of flooding insurance in the Netherlands, one would expect the WTS to provide public funds in cases where the insurance market fails. However, as shown above, given the particular legal structure of the WTS, the public budget does indeed largely intervene, but rather on an ad hoc basis than through the WTS. Moreover, one can hardly refer to a public-private partnership given that private insurances for flooding are simply not available. The situation is only different in the case of damage due to heavy rainfall. As regards agricultural damage, a tool has been created by insurers, backed by a government guarantee to cover damage up to a set amount - with the central government intervening beyond that. For this intervention, neither insurers nor the agricultural sector pays, hence the European state aid procedure has had to be (successfully) followed. This crop damage insurance can be considered therefore as a public-private partnership since the government intervenes to provide a second layer of compensation. However, one wonders why insurers (and politicians) were willing and able to offer this solution for crop damage suffered by the agricultural sector, but not for other types of damage resulting from natural disasters. The Government of the Netherlands wanted to move away from ad hoc compensation, but the price to be paid was a substantial subsidy since no price is charged for the government guarantee.

In sum, one can argue that to some extent (albeit in different forms) some type of public-private partnership has emerged in both countries for the compensation of damage caused by particular natural catastrophes.

\section{Incentive-based financing?}

A crucial issue for any compensation scheme for natural disasters is whether it is possible to construct a compensation system in such a way that the financing can be (to some point) incentive-based in so far as providing inducements to potential 
parties involved in the prevention of risk, such as location choice or adopting specific preventive measures. This implies that differentiation takes place whereby those who are more exposed to particular risks contribute more to a scheme than others. This simple idea of differentiating financial contributions reflects the notion that the financing system would still offer incentives for prevention. However, individual options to minimise risk resulting from natural disasters may not always be available. For example, in the Netherlands, given the low-lying nature of the area, flood risk prevention may be to a significant degree a public good. The extent to which incentive-based financing should occur is dependent to a large extent therefore on the possibilities of using private flood prevention strategies.

Comparing the Belgian and Dutch systems in this respect it is easy to argue that the traditional Belgian Disaster Fund and Dutch public solutions (under the WTS I998 or ad hoc) are problematic in the sense that financing is provided through the public budget and not related to the risks posed by the particular beneficiaries of the compensation. The remaining public solutions in both countries are (almost by definition) always limited and never supply full compensation. The fact that potential victims thus are still partially exposed to the risk can of course still provide incentives for prevention.

As far as insurance is concerned, the level to which crop damage insurance (the only one available) in the Netherlands provides for risk differentiation and is incentivebased is unclear. A problem here is that only two insurance companies offer coverage. The literature often has indicated that competition is an important driving force for insurance companies to differentiate risks. With only two players in the market (both mutuals), one wonders about the extent to which insurers have sufficient incentives to differentiate premiums adequately. In Belgium, the premium to be charged for additional flooding coverage has not been regulated and consequently can be the subject of competition. As a result, insurers can adapt the premium, taking into account the particular situation of every insured residence (such as location in a flood-prone area).

A question of particular interest concerning the Belgian situation is why general mandatory coverage of flood risks has been introduced for all possessors of a fire insurance policy. The alternative was in the Act of 2I May 2003: limit mandatory coverage to specific flood-prone areas. Thus one could avoid the situation of those who pose no risk at all (for example, by living in an apartment in a city on the tenth floor) also being forced to purchase the additional coverage for which they have no demand. The costs of determining these flood-prone areas were apparently so high that it appeared impossible to demarcate them. As a result, the Act of I7 September 2005 forced all citizens with fire insurance coverage to take out additional mandatory coverage for natural catastrophes. Hence there is some cross-subsidisation, but the inhabitant of a tenth-floor apartment will still pay a lower premium than a person living in a flood-prone area.

One also wonders why insurance coverage has to be made mandatory. Instead, information could be supplied to potential victims about the possibility of purchasing 
insurance coverage and they could decide whether to do so based on their own preferences. However, empirical research shows that without mandatory insurance only a small percentage of citizens take out catastrophe insurance. This was demonstrated in Germany after the Elbe flooding in 2002 (Endres, Ohl and Rundshagen, 2003) as well as in the United States after Hurricane Katrina (Kunreuther, 2006b). Moreover, behavioural experiments have shown that social welfare can be increased by adding protection against low probability but large-scale losses, such as disasters, to insurance for small but more likely losses, such as fire insurance (Slovic, Kunreuther and White, 2000). These findings have led several economists to assert that there are strong arguments in favour of a so-called comprehensive disaster insurance whereby potential victims would be forced to purchase disaster coverage in addition to fire insurance, a point advanced by Howard Kunreuther, for instance, repeatedly since I968 (Kunreuther, I968; see also Kunreuther, 2006b; Schwarze and Wagner, 2004).

\section{Concluding remarks}

This paper has addressed a few recent developments concerning compensation for victims of natural catastrophes in Belgium and the Netherlands. To this end, the paper comprises a descriptive analysis that enables a historical comparison to be made from a law and economics perspective.

Since there is no liable tortfeasor in the event of natural catastrophes, the possibilities for tort law to provide compensation are limited. Victims, therefore, often will seek other solutions. Given the high number of victims (especially after a flood) it should not come as a surprise that politicians find it hard to resist offering compensation. The developments outlined in this paper, however, show that whereas the pattern to strive for less liability on the part of the government and the application of market mechanisms (more particularly insurance) is similar, important differences exist in the current legal structures of the two countries (even though the evolution process has yet to be finalised in the Netherlands). ${ }^{32}$

Belgium started with public budget-based compensation via a Disaster Fund, but it has now largely followed the French example of mandatory coverage for particular natural disasters (including flooding) in addition to (voluntarily purchased) fire insurance. A major difference, though, is that in Belgium the additional premium has not been regulated. The premium thus can be the object of competition between insurers and a differentiation also can manifest itself corresponding to the particular risks posed by the insured. However, the Government of Belgium still intervenes, for example in the event that someone cannot obtain insurance coverage for a particular risky area or for particular elements of the damage not covered by insurance. The role of the Disaster Fund today is, however, much more limited following the introduction of compulsory insurance.

The Netherlands also has debated the introduction of compulsory insurance but instead opted to introduce a public budget solution in the WTS 1998. Given the 
limited scope of the WTS I998 and the tendency of the country's government always to provide ad hoc compensation after every new disaster, suggestions have been made to make greater use of first-party insurance. Yet, until now, insurers only have offered coverage for crop damage in the agricultural sector. That no insurance coverage is available for the remaining (ordinary) flood risks in the Netherlands leads, inter alia, to serious questions about competition law. Although the binding decisions (prohibiting the coverage of earthquake and flood risks) have been withdrawnunder EU pressure - this has seemingly not led to a change in the behaviour of Dutch insurers. Floods may be difficult to insure given the lack of sufficient statistical data. Flood losses also may be potentially too high for insurers alone, requiring therefore reinsurance and/or government intervention in the case of large losses.

In the area of crop damage insurance an interesting public-private partnership has emerged: the Government of the Netherlands provides a second layer of compensation, which under EU competition rules is considered an outright subsidy, but is permitted by the EU Commission. Even though the scope of the compensation regime in the Netherlands today is still far more limited than that in Belgium, the evolution of crop damage insurance is similar: the combination of basic insurance and a government guarantee for amounts not covered by the insurer.

The comparison of the compensation systems in Belgium and the Netherlands also gives rise to many questions that fall outside the scope of this paper. For example, why was it possible to develop private solutions (insurance) to cover natural disasters (especially flooding) in Belgium and why has this proved more problematic in the Netherlands? Is this related to the catastrophic incidents experienced by these two countries or is it due to path dependency or interest group activity? The way in which the compensation systems actually affects the incentives of potential parties involved in the prevention of risks is an important issue as well. These are questions that undoubtedly could be explored in subsequent research.

Of course, it is still too early to offer a definitive evaluation of both systems. Many commentators have criticised the shortcomings of the current compensation system in the Netherlands. It has not led Dutch insurers towards a fundamental change in providing flood insurance for ordinary citizens. Another serious flood (or other natural disaster) is perhaps required to put this item on the political agenda again. Mandatory coverage in Belgium, meanwhile, has been in force now for more than five years and seems to be working satisfactorily. However, the next large flood will show to what extent the new system is able to provide adequate coverage or whether the Disaster Fund is still necessary.

\section{Correspondence}

Prof. Dr Michael Faure, Maastricht University - METRO, P.O. Box 6I6, 6200 MD Maastricht, The Netherlands. Telephone: +3 I (o) 43 3883060; fax: +3 I (o) 43 3883203; e-mail: michael.faure@maastrichtuniversity.nl 


\section{Endnotes}

I Dr Véronique Bruggeman LLM is Model Product Manager, Risk Management Solutions, United Kingdom-Dr Bruggeman holds a PhD from Maastricht University on compensating victims of catastrophes, which was published by Kluwer Law International; Prof. Dr Michael Faure LLM is Professor of Comparative and International Environmental Law, Maastricht University, Academic Director of the Maastricht European Institute of Transnational Legal Research (METRO) and the Ius Commune Research School, Professor of Comparative Private Law and Economics, Erasmus University Rotterdam, and Academic Director, Rotterdam Institute of Law and Economics (RILE), The Netherlands; and Dr Miriam Haritz MA is Legal Advisor and Head of the Presidential Office at the Federal Office of Civil Protection and Disaster Assistance, Germany-Dr Haritz holds a PhD from Maastricht University on climate change liability and the application of the precautionary principle, which is to be published by Kluwer Law International in 20 I I.

2 The French system, despite being a popular export model for legal systems considering reform of their compensation system, is not discussed further in this contribution, since it is the subject of many previous studies.

3 Theoretically, victims of natural catastrophes also could use liability law, but in practice scope will be limited since in most cases no injurer can be held liable for the natural catastrophe. The only imaginable case would be the one whereby the public authorities would have, for example, failed in their supervisory duties or failed to take measures to prevent the catastrophe. However, this paper will not discuss the (largely theoretical) possibilities of government liability at great length for the simple reason that in neither Belgium nor the Netherlands this is in practice an important source of compensation for victims.

4 Explanatory Memorandum, Parliamentary Proceedings of the Chamber of Representatives 2004-5, no. I732/OoI, p. 7 .

5 Recognition of an event as a disaster is a political decision, in which other more than purely technical motives also play a role. Nevertheless, to be declared a natural disaster, the phenomenon needs to have an exceptional character and have caused considerable damage. The criteria are as follows: total damage must amount to at least EUR I,239,467.60; average damage must amount to at least EUR 5,577.60 per family; and the phenomenon must have a retain period of a maximum of once every 20 years (Ministerial Circular of 30 November 200I).

6 Fire insurance coverage for simple risks relates to: I) every good or entity of goods of which the insured value does not add up to more than EUR 743,680.57; and 2) the insured value of each of the following goods is below EUR 23,921,725.I4: a. offices and houses, including apartments or office buildings as far as the surface used for commercial purposes does not amount to more than 20 per cent of the total surface of all the floors; b. agricultural, garden and viniculture companies, fruit and cattle-breeding companies; c. places used for the exercise of professions, with the exception of pharmacies; $d$. places used for religious events, such as for masses, abbeys and cloisters; e. places used for cultural, social and philosophical activities; f. buildings used for education, with the exception of higher education; g. music conservatories, museums and libraries; h. installations that are exclusively used for sport activities; and i. institutes for medical treatment, sanatoria, hospitals, clinics and rest homes. The mentioned amounts are coupled to the ABEX (Association Belge des Experts)-index, with a basic index of 375 .

7 'In the main insured' means that that part of the premium that concerns the aforementioned risks constitutes at least 50 per cent of the total premium.

8 Explanatory Memorandum, Parliamentary Proceedings of the Chamber of Representatives 2004-5, no. I732/OoI. 
9 The following events also are considered as a flood: the overflowing of riverbanks, canals, lakes, ponds or seas or an overflow, impoundment of public sewers, or a rupture of dikes, as a consequence of atmospheric precipitation, a storm, the melting of snow or ice, or a tidal wave.

10 Chamber of Representatives, 25 April 2005, DOC 5I I732/00I, 2004-5, p. I4.

II The fire insurer is entitled nevertheless to refuse insurance of flooding in the event that (part of) the building was constructed more than I 8 months after the publication in the Belgian Gazette of the Royal Decree that classifies the building as being in a flood-prone area. The ratio legis of this exception lies in the empowerment of, on the one hand, the local administrations not to grant building licences, and, on the other hand, the owners who know that they reside in a risk area.

${ }^{12}$ Explanatory Memorandum, Chamber of Representatives 2004-5, no. I732/oor, p. I5. The actual losses and needs for compensation can be much higher than the tens of millions of Euros mentioned in the Belgian parliament. First, the numbers that are given are not corrected for inflation and current risks may be higher due to ongoing population growth and accumulation of capital. Second, historic losses over the short period of existence of the Belgian fund (approximately 25 years) are likely to be lower than the probable maximum losses that can be estimated using loss models. Hence, flooding in Belgium can inflict more damage than the amounts mentioned in the Belgian parliament.

${ }^{13}$ Documents of the Second Chamber of Representatives I993-I994, 23 564, no. 3.

${ }^{14}$ Official Journal L 398/7 of 3 I December I992.

is In its report to the European Parliament of I2 May I999 concerning the operation of the exemption Regulation 3932/92 (COM [I999] 92 final) the European Commission explicitly discussed these binding decisions, stating that, as a result of the questions asked by the Commission, the Dutch Association of Insurers had decided to bring its binding decisions into line with the regulation by simply converting the binding decision into a non-binding recommendation, leaving each insurer free to extend cover to flood risks.

${ }^{16}$ Documents of the Second Chamber of Representatives I999-2000, 24 07I, no. 55 et seq.

${ }^{17}$ Documents of the Second Chamber of Representatives 2002-2003, 2407I, no. 59, I.

${ }^{18}$ Documents of the Second Chamber of Representatives 2002-2003, 24 07I, no. 60.

19 Documents of the Second Chamber of Representatives 2003-2004, 24 07I, no. 63; C (2003) 355I fin, in Dutch.

${ }^{20}$ OWM AquaPol decided to cease its insurance activities from 2009, due to the limited number of insured parties.

${ }^{21}$ Documents of the Second Chamber of Representatives 2004-2005, 24 07I, no. 65.

${ }^{22}$ See C(2007)3096, in Dutch.

23 Documents of the Second Chamber of Representatives I993-I994, 23400 VII, no. 34, 2.

${ }^{24}$ Documents of the Second Chamber of Representatives I995-I996, 26 640, no. I, 2-3.

25 Documents of the Second Chamber of Representatives I996-I997, 25 I59, no. 3, 4-5.

${ }^{26}$ Documents of the Second Chamber of Representatives I996-I997, 25 I59, no. 5, 25-26.

27 Documents of the Second Chamber of Representatives I996-I997, 25 I59, no. 3 I5.

${ }_{28}$ Documents of the Second Chamber of Representatives I996-I997, 25 I59, no. 5, 7.

29 Documents of the Second Chamber of Representatives 200I-2002, 27 I57, no. 44, 4.

${ }^{30}$ See the Act of 23 June 2005 on the Amendment of the Civil Code and the Code of Civil Legal Procedure in order to facilitate Class Action, Staatscourant, 5 July $2005,340$.

${ }^{31}$ Documents of the Second Chamber of Representatives 2006-2007, 29 668, no. II.

32 The underlying socio-political reasons behind the different starting points and developments in the two neighbouring countries are beyond the scope of this paper and necessitate further academic research. 


\section{References}

Assuralia (ed.) (2005) 'De natuurrampendekking'. Assurinfo. I9 October.

Bernauw, K. (2006) 'De verzekering van natuurrampen'. Bulletin des Assurances - De Verzekering. pp. I53-I68.

Bloembergen, A.R. (I992) 'Een schadefonds geweldsmisdrijven?'. In A.R. Bloembergen (ed.) Bloembergens werk. Kluwer, Deventer. pp. I67-I78

Bruggeman, V. (2010) Compensating Catastrophe Victims. A Comparative Law and Economics Approach. Kluwer Law International, Alphen aan den Rijn.

Celis, C. and M. de Graeve (2006) 'De overstromingsverzekering: een slag in het water?'. Tijdschrift Verkoop Vastgoed. pp. 529-549.

Colle, P. (2005) Handboek Bijzonder Gereglementeerde Verzekeringscontracten. Intersentia, Antwerpen.

Colle, P. (2005-06) 'De wet van I7 september 2005 betreffende de verzekering van natuurrampen'. Rechtskundig Weekblad. pp. 88I-885.

de Graeve, M. (2006) 'De natuurrampenverzekering: de kogel is eindelijk door de kerk'. Tijdschrift voor Wetgeving. pp. $8 \mathrm{I}-86$.

de Groot, J.F. (2004) 'Na de ramp. Een beschouwing over de toepassing van de WTS'. Overheid en Aansprakelijkheid. pp. I4I-I52.

de Vries, F.J. (I998) 'Vergoeding van Rampschade'. Nederlands Juristen Blad. pp. I908-I9I3.

Durant, I. (2006) 'Belgium'. In M. Faure and T. Hartlief (eds.) Financial Compensation for Victims of Catastrophes. A Comparative Legal Approach. Springer-Verlag, Vienna. pp. 37-79.

Endres, A., C. Ohl and B. Rundshagen (2003) 'Land unter! Ein institutionenökonomischer Zwischenruf'. List Forum für Wirtschafts- and Finanzpolitik. pp. 284-294.

Epstein, R. (I996) 'Catastrophic responses to catastrophic risks'. Journal of Risk and Uncertainty. I2(2-3). pp. $287-308$.

Faure, M. and T. Hartlief (2007) 'The Netherlands'. In H. Koziol and B.C. Steininger (eds.) European Tort Law 2006. Springer, Vienna. pp. 338-360.

Faure, M. and T. Hartlief (2006) 'The Netherlands'. In M. Faure and T. Hartlief (eds.) Financial Compensation for Victims of Catastrophes. A Comparative Legal Approach. Springer-Verlag, Vienna. pp. I95-260.

Faure, M. and T. Hartlief (2003) Insurance and Expanding Systemic Risks. Organisation for Economic Co-operation and Development, Paris.

Faure, M. and T. Hartlief (200Ia) 'Vergoeding van rampschade'. In E.R. Muller and C.J.J. M. Stolker (eds.) Ramp en Recht. Boom Juridische Uitgevers, Leiden. pp. I49-I72.

Faure, M. and T. Hartlief (200Ib) 'Schade als gevolg van natuurverschijnselen: de betekenis van de WTS'. Milieu en Recht (MenR). pp. 240-246.

Faure, M. and R. Van den Bergh (2002) 'Competition on the European market for liability insurance and efficient accident law'. Maastricht Journal of European and Comparative Law. 9(3). pp. 279-306.

Froot, K.A. (1999) The Financing of Catastrophe Risks. University of Chicago Press, Chicago, IL.

Gollier, C. (2005) 'Some aspects of the economics of catastrophe risk insurance'. Catastrophic Risks and Insurance. Organisation for Economic Co-operation and Development, Paris. pp. I3-30.

Hartlief, T. (I995) 'Vergoeding van watersnoodschade'. In M. Faure and F. Stroink (eds.) Recht in het water. De juridische aspecten van watersnood. MAKLU, Antwerpen-Apeldoorn. pp. I3I-I42.

Hartlief, T. (2002) 'Schadefondsen en de rol van de overheid'. In J.M. Barendrecht et al. (eds.) Kring van aansprakelijken bij massaschade. Vermande, Lelystad. pp. 6I-IO3.

IPCC (Intergovernmental Panel on Climate Change) (2007) IPCC Fourth Assessment Report: Climate Change 2007. Cambridge University Press, Cambridge. http://www.ipcc.ch/publications_and_data/ publications_and_data_reports.shtml\# I.

Kaplow, L. (I99I) 'Incentives and government relief for risk'. Journal of Risk and Uncertainty. 4(2). pp. I67-I75.

Kok, M., H.F. Dooper and I.B.M. Lammers (2000) 'Verzekeren van regenschade'. Het Waterschap. pp. $803-807$. 
Kunreuther, H. (I968) 'The case for comprehensive disaster insurance'. Journal of Law and Economics. II (I). pp. I33-I63.

Kunreuther, H. (2006a) 'Has the time come for comprehensive natural disaster insurance?'. In R.J. Daniels, D.F. Cattle and H. Kunreuther (eds.) On Risk and Disaster. Lessons from Hurricane Katrina. University of Pennsylvania Press, Philadelphia., PA. pp. I75-20I.

Kunreuther, H. (2006b) 'Disaster mitigation and insurance: learning from Katrina'. The Annals of the American Academy of Political and Social Science. 604(I). pp. 208-227.

Kunreuther, H. and E. Michel-Kerjan (2004) 'Challenges for terrorism risk insurance in the United States'. Journal of Economic Perspectives. I8 (4). pp. 20 I-2 I 4.

Lafay, F., M. Cannarsa and O. Moréteau (2006) 'France'. In M. Faure and T. Hartlief (eds.) Financial Compensation for Victims of Catastrophes: A Comparative Legal

Approach. Springer-Verlag, Vienna. pp. 8I-II8.

Levie, G. and H. Cousy (eds.) (I994) La politique Européenne de concurrence en matière dassurance. Bruylant, Brussels.

Leyssen, M. (2005) Verzekeren tegen natuurrampen: reactie van de wetgever, de verzekeringssector en de financiële markt. Faculteit Economische en Toegepaste Economische Wetenschappen, Departement Toegepaste Economische Wetenschappen, Katholieke Universiteit Leuven, Leuven

Muller, E.R. and C.J.J.M. Stolker (eds.) (200Ia) Ramp en Recht. Boom Juridische Uitgevers, Leiden.

Muller, E.R. and C.J.J.M. Stolker (200Ib) 'Overheidsaansprakelijkheid en toezicht'. Nederlands Juristen Blad pp.I647-I698.

Nijs, L. (200I) 'Wateroverlast en de rol van de verzekeringswereld'. Ruimte voor water, de beste verzekering tegen wateroverlast. I5 May. AMINAL and KBC, Brussels.

Polak, J.M. (I997) 'Schade en schadevergoeding bij incidentele calamiteiten. Een vervolg'. Nederlands Juristen Blad. pp. I093-I094.

Posner, R.A. (2007) Economic Analysis of Law. Seventh edition. Wolters Kluwer Law and Business, Aspen Publishers, New York, NY.

Priest, G. (I996) 'The government, the market and the problem of catastrophic loss'. Journal of Risk and Uncertainty. I2(2-3). pp. 219-237.

Schwarze, R. and G. Wagner (2004) 'In the aftermath of Dresden. New directions in German flood insurance'. Geneva Papers on Risk and Insurance. 29(2). pp. I54-I68.

Slovic, P., H. Kunreuther and G.F. White (2000) 'Decision processes, rationality and adjustment to national hazards'. In P. Slovic (ed.) The Perception of Risk. Earthscan, London. pp. I-3I.

Termote, K. (I998) 'Naar een verplichte dekking van natuurrampen?'. Balans. 375. pp. 6-7.

Termote, K. (2000) 'Natuurrampen: nieuwe poging tot regeling'. Balans. 423. pp. 4-5.

Termote, K. (2003) 'Verplichte overstromingsverzekering: niet voor iedereen'. Balans. 473. pp. 5-7.

Termote, K. (2006) 'Natuurrampenverzekering: sinds I maart in voege'. Balans. 538. pp. 5-7.

Van de Bunt, J.E. (200I) 'Voorgeschiedenis van de WTS. Beschouwing over verschillende regelingen ter vergoeding van rampschade'. In E.R. Muller and C.J.J.M. Stolker (eds.) Ramp en Recht. Boom Juridische Uitgevers, Leiden. pp. I73-203.

Van den Wall Bake, D.W.P.E.M. Van Dijk, N. Kastelein, M.R. Schurink and M.W.G. Steinmeijer (2004) Eindrapportage. Inventarisatie van financiële voorzieningen na rampen in Nederland. Solidariteit met Beleid. Aanbevelingen over Financiële Tegemoetkomingen bij Rampen en Calamiteiten. Bureau Berenschot, Utrecht.

Van der Schans, E. (2000) 'Regen als ramp. Wateroverlast en de WTS'. Tijdschrift voor Milieuaansprakelijkheid (TMA). pp. I3-I9.

Van Ravels, B. (2006) 'Is de overheid aansprakelijk als er sprake is van falend toezicht?'. Externe Veiligheid. pp. 4-8.

Van Schoubroeck, C. (2003) 'The quest for private insurance for damage caused by natural disasters: a Belgian case'. Journal of Business Law. 6. pp. 558-57I. 